\title{
In vitro Tissue Culture, a Tool for the Study and Breeding of Plants Subjected to Abiotic Stress Conditions
}

\author{
Rosa Ma Pérez-Clemente and Aurelio Gómez-Cadenas
}

Additional information is available at the end of the chapter

http://dx.doi.org/10.5772/50671

\section{Introduction}

Abiotic stress factors are the main limitation to plant growth and yield in agriculture. Among them, drought stress caused by water deficit, is probably the most impacting adverse condition and the most widely encountered by plants, not only in crop fields but also in wild environments. According to published statistics, the percentage of droughtaffected land area in the world in 2000 was double that of 1970 [1].

Another major environmental factor that limits crop productivity, mainly in arid and semiarid regions is high salinity. Approximately $19.5 \%$ of the irrigated soils in the world have elevated concentrations of salts either in the soil or in the irrigation water [2], damaging both the economy and the environment $[3,4]$. The deleterious effects of salinity on plant growth are associated with low osmotic potential of soil solution (water stress), nutritional imbalance, specific ion effect (salt stress), or a combination of these factors [5].

Abiotic stress leads to a series of morphological, physiological, biochemical, and molecular changes that adversely affect plant growth and productivity [6]. Drought, salinity, extreme temperatures, and oxidative stress are often interconnected, and may induce similar cellular damage (for more details see [7]).

During the course of its evolution, plants have developed mechanisms to cope with and adapt to different types of abiotic and biotic stress. Plants face adverse environmental conditions by regulating specific sets of genes in response to stress signals, which vary depending on factors such as the severity of stress conditions, other environmental factors, and the plant species [8].

The sensing of these stresses induces signaling events that activate ion channels, kinase cascades, production of reactive oxygen species, and accumulation of hormones [9]. 
These signals ultimately induce expression of specific genes that lead to the assembly of the overall defense reaction. In contrast to plant resistance to biotic stresses, which is mostly dependent on monogenic traits, the genetically complex responses to abiotic stresses are multigenic, and thus more difficult to control and engineer [10].

The conventional breeding programs are being used to integrate genes of interest from inter crossing genera and species into the crops to induce stress tolerance. However, in many cases, these conventional breeding methods have failed to provide desirable results [11].

In recent decades, the use of techniques based on in vitro plant tissue culture, has made possible the development of biotechnological tools for addressing the critical problems of crop improvement for sustainable agriculture. Among the available biotechnological tools for crop breeding, genetic engineering based on introgression of genes that are known to be involved in plant stress response and in vitro selection through the application of selective pressure in culture conditions, for developing stress tolerant plants, have proved to be the most effective approaches [12].

On the other hand, it is often difficult to analyze the response of plants to different abiotic stresses in the field or in greenhouse conditions, due to complex and variable nature of these stresses. In vitro tissue culture-based tools have also allowed a deeper understanding of the physiology and biochemistry in plants cultured under adverse environmental conditions [13].

In this work, the progress made towards the development of abiotic stress-tolerant plants through tissue culture-based approaches is described. The achievements in the better understanding of physiological and biochemical changes in plants under in vitro stress conditions are also reviewed.

\section{Somaclonal variation}

Somaclonal variation is defined as the genetic and phenotypic variation among clonally propagated plants of a single donor clone. It is well known that genetic variations occur in undifferentiated cells, isolated protoplasts, calli, tissues and morphological traits of regenerated plants. The cause of variation is mostly attributed to changes in the chromosome number and structure. Generally, the term somaclonal variation is used for genetic variability present among all kinds of cells/plants obtained from cells cultured in vitro [14].

Plants regenerated from tissue and cell cultures show heritable variation for both qualitative and quantitative traits. Somaclonal variation caused by the process of tissue culture is also called tissue culture-induced variation to more specifically define the inducing environment [15]. The occurrence of uncontrolled and spontaneous variation during the culture process is an unexpected and mostly undesired phenomenon when plants are micropropagated at the commercial scale [16]. However, apart from these negative effects, its usefulness in crop breeding through creation of novel variants has been extensively reported [17]. Induced somaclonal variation can be used for genetic manipulation of crops with polygenic traits 
[18]. The new varieties derived from in vitro tissue culture could exhibit disease resistance and improvement in quality as well as better yield [19].

Somaclonal variants can be detected using various techniques which are broadly categorized as morphological, physiological/biochemical and molecular detection techniques. There are two main approaches for the isolation of somaclonal variants: screening and cell selection.

Screening involves the observation of a large number of cells or regenerated plants for the detection of variant individuals. Mutants for several traits can be far more easily isolated from cell cultures than from whole plant populations. This is because a large number of cells can be easily and effectively screened for mutant traits. Screening of as many plants would be very difficult, ordinarily impossible [17]. Mutants can be effectively selected for disease resistance, improvement of nutritional quality, adaptation to stress conditions, e.g., saline, soils, low temperature, toxic metals, resistance to herbicides and to increase the biosynthesis of plant products used for medicinal or industrial purposes. Screening has been profitably and widely employed for the isolation of cell clones that produce higher quantities of certain biochemicals [20].

In the cell selection approach, a suitable pressure is applied to permit the preferential survival/growth of variant cells. Selection strategies have been successfully developed for the recovery of genotypes resistant to various toxins, herbicides, high salt concentration etc. [21]. When the selection pressure allows only the mutant cells to survive or divide, it is called positive selection. On the other hand, in the case of negative selection, the wild type cells divide normally and therefore are killed by a counter selection agent, e.g., 5Bromodeoxyuridine, or arsenate. The mutant cells are unable to divide as a result of which they escape the counter selection agent. These cells are subsequently rescued by removal of the counter selection agent [11].

\section{In vitro selection of plants tolerant to abiotic stress}

Many studies have reported that the in vitro culture alone or combined with mutagenesis, induced with physicochemical or biological agents, can be exploited to increase genetic variability and mutants, as a potential source of new commercial cultivars [22]. In vitro culture environments can be mutagenic and plants regenerated from organ cultures, calli, protoplasts and via somatic embryogenesis sometimes exhibit phenotypic and/or genotypic variations [22].

It is important to point that tissue culture increases the efficiency of mutagenic treatments and allows handling of large populations and rapid cloning of selected variants [17]. The similarities of the effects induced by the stress in the plant cultured in vitro and in vivo conditions suggest that the in vitro system can be used as an alternative to field evaluations for studying the general effect of water-stress on plant growth and development.

The most widely used method for the selection of genotypes tolerant to abiotic stress is the in vitro selection pressure technique. This is based on the in vitro culture of plant cells, 
tissues or organs on a medium supplemented with selective agents, allowing selecting and regenerating plants with desirable characteristics. In table 1 a list of species in which this technique has been successfully applied to obtain genotypes with increased resistance to different abiotic stresses is shown.

\begin{tabular}{|c|c|c|}
\hline Plant species & stress & References \\
\hline $\begin{array}{l}\text { Chrysanthemum morifolium } \\
\text { (chrysanthemum) }\end{array}$ & salt & [66] \\
\hline Brassica napus (rapeseed) & salt & [67] \\
\hline Citrus aurantium (sour orange) & salt & {$[68]$} \\
\hline Lycopersicon esculentum (tomato) & salt & [69] \\
\hline Dendrocalamus strictus (bamboo) & salt & [11] \\
\hline Ipomoea batatas (sweet potato) & salt & [70] \\
\hline Saccharum sp. (sugarcane) & salt & {$[71]$} \\
\hline Solanum tuberosum (potato) & salt & [32], [72] \\
\hline Triticum aestivum (wheat) & salt & [21], [73] \\
\hline Arachis hypogaea (groundnut) & drought & [74] \\
\hline Brassica juncea (indian mustard) & drought & [75] \\
\hline Prunus avium (colt cherry) & drought & [72] \\
\hline Saccharum sp. (sugarcane) & drought & [76] \\
\hline Oryza sativa (rice) & drought/chilling/Al & [77] \\
\hline Triticum aestivum (wheat) & drought/frost & [73] \\
\hline Glycine max (soybean) & $\mathrm{Al}$ & [78] \\
\hline Setaria italica (millet) & $\mathrm{Zn}$ & [79] \\
\hline
\end{tabular}

Table 1. In vitro selection for increased resistance to abiotic stresses.

The most important successes on this respect are described below:

\subsection{In vitro selection of salt-tolerant plants}

The problem of soil salinity has been aggravated during the last decades as a consequence of some agricultural practices such as irrigation and poor drainage systems. As described in the introduction, it has been estimated that around $20 \%$ of the irrigated land in the world is affected by salinity, and it is expected that the increase of salinization in agricultural fields will reduce the land available for cultivation by $30 \%$ in the next 25 years and up to $50 \%$ by the year 2050 [23].

The in vitro selection pressure technique has been effectively utilized to induce tolerance to salt stress in plants through the use of salts as a selective agent, allowing the preferential survival and growth of desired genotypes. This approach has being done using a number of plant materials (callus, suspension cultures, somatic embryos, shoot cultures, etc.) which has been screened for variation in their ability to tolerate relatively high levels of salt in the culture media. In most of the studies, the salt used has been $\mathrm{NaCl}$ [24]. 
Several researchers have compared the response of other $\mathrm{Cl}^{-}$and $\mathrm{SO}_{4}{ }^{2-}$ salts including $\mathrm{KCl}$, $\mathrm{Na}_{2} \mathrm{SO}_{4}$, and $\mathrm{MgSO}_{4}$ during in vitro screening. This use of multiple salts as a selection pressure parallels the salinity under field conditions and may be a better choice [11].

\subsection{In vitro selection of drought-tolerant plants}

Drought is a major abiotic stress which causes important agricultural losses, mainly in arid and semiarid areas. Drought stress causes moisture depletion in soil and water deficit with a decrease of water potential in plant tissues. In vitro culture has been used to obtain droughttolerant plants assuming that there is a correlation between cellular and in vivo plant responses [25]. During the last years, in vitro selection for cells exhibiting increased tolerance to water or drought stress has been reported (Table 1).

Polyethylene glycol (PEG), sucrose, mannitol or sorbitol have been used by several workers as osmotic stress agents for in vitro selection [25; 26] However, PEG has been the most extensively used to stimulate water stress in plants. This compound of high molecular weight is a non-penetrating inert osmoticum that reduces water potential of nutrient solutions without being taken up by the plant or being phytotoxic [26]. Because PEG does not enter the apoplast, water is withdrawn not only from the cell but also from the cell wall. Therefore, PEG solutions mimic dry soil more closely than solutions of compounds with low molecular weights, which infiltrate the cell wall with solute [27].

Besides salt and drought, a few reports are also available for the development of plants tolerant to other abiotic stress (metal, chilling, UV and frost) through in vitro selection (Reviewed in [11]).

\section{Characterization of salt- or drought-tolerant plants during in vitro selection}

A second step in the process of obtaining genotypes more tolerant to a particular stress condition is the characterization of the regenerants that survive to the imposed pressure selection under in vitro conditions. Salinity and drought affect many physiological processes such as reductions of cell growth, leaf area, biomass and yield. The activation of the plant antioxidant defense system has been positively associated with salt and drought tolerance [11], and the same pattern has been confirmed on in vitro cultures [28]. Therefore, by measuring antioxidant activities in vitro, a rapid preliminary selection of tolerant genotypes could be performed. In fact, different authors have determined the main antioxidant enzymes such as superoxide dismutase (SOD), ascorbate peroxidase (APX), catalase (CAT) and glutathione reductase (GR) [29].

Lipids play an important role as the structural constituent of most of the cellular membranes [30]. Moreover, often there is no need of intact plants to perform the initial selection, as in the case of callus culture that can be used as a plant material for the selection of tolerant genotypes. As an example it is well known that free radical-induced peroxidation of lipid membrane is a sign of stress-induced damage at cellular level. Therefore, the level of 
malonyldialdehyde, produced during peroxidation of membrane lipids, is often used as an indicator of oxidative damage [31]. It has been reported that selected callus lines of Solanum tuberosum subjected to $\mathrm{NaCl}$ showed an increase in lipid peroxidation in comparison with salt tolerant lines [32].

For overcoming salt or drought stress, plants have developed protective mechanisms including osmotic adjustment that is usually accomplished by accumulation of compatible solutes such as proline, glycine betaine and polyols [33]. It has been also reported that proline levels increased in response to water stress in tomato calli [34].Taking into account the generated knowledge about plants responses to abiotic stress conditions, the determination of antioxidant enzyme activities, and levels of malonyldialdehyde and proline in plants recovered under selective conditions may help to isolated the most tolerant genotypes.

In recent years, both basic and applied research has led to understand the mechanisms underlying the stress response and the identification of the specific genes/metabolites that are responsible for tolerance phenotypes the "omics" approaches have had a significant development. Through the application of transcriptomics hundreds of genes have been linked with environmental stress responses and regulatory networks of gene expression have been delineated [35]. Moreover, plant tolerance to abiotic stress conditions has been associated with changes in proteome composition. Since proteins are directly involved in plant stress response, proteomics studies can significantly contribute to unravel the possible relationships between protein abundance and plant stress acclimation [36].

Relatively less is known about changes at the metabolomic level. Metabolome analysis has become a valuable tool to study plant metabolic changes that occur in response to abiotic stresses. This approach has already enabled to identify different compounds whose accumulation is affected by exposure to stress conditions. However, much work is still required to identify novel metabolites and pathways not yet linked to stress response and tolerance [37].

In this context, an integrated approach incorporating in vitro plant tissue culture to proteomics and metabolomics technique, can contribute to elucidate the metabolites involved in stress response and select desired genotypes at early stages of plant development or at callus stage [38].

\section{Transgenesis for abiotic stress tolerance}

Transgenic approaches are among the available tools for plant improvement programs based on biotechnological methodologies. Nowadays, many mechanisms and gene families, which confer improved productivity and adaptation to abiotic stresses, are known. These gene families can be manipulated into novel combinations, expressed ectopically, or transferred to species in which they do not naturally occur. Therefore, the possibility to transform the major crop species with genes from any biological source (plant, animal, microbial) is an extremely powerful tool for molecular plant breeding [39]. 
To date, successes in genetic improvement of environmental stress resistance have involved manipulation of a single or a few genes involved in signaling/regulatory pathways or that encode enzymes involved in these pathways (such as osmolytes/compatible solutes, antioxidants, molecular chaperones/osmoprotectants, and water and ion transporters [8]. The disadvantage of this approach is that there are numerous interacting genes involved, and efforts to improve crop drought tolerance through manipulation of one or a few of them is often associated with other, often undesirable, pleiotropic and phenotypic alterations [8].

The plant hormone abscisic acid (ABA) regulates the adaptive response of plants to environmental stresses such as drought, salinity, and chilling via diverse physiological and developmental processes $[40,41]$.

The ABA biosynthetic pathway has been deeply studied and many of the key enzymes involved in ABA synthesis have been used in transgenic plants in relation to improving abiotic stress tolerance [42]. Transgenic plants overexpressing the genes involved in ABA synthesis showed increased tolerance to drought and salinity stress [42, 43]. Similarly, many studies have illustrated the potential of manipulating CBF/DREB genes to confer improved drought tolerance [44, 45].

Another mechanism involved in plant protection to osmotic stress associated to drought and salinity involves the upregulation of compatible solutes that function primarily to maintain cell turgor, but are also involved in avoiding oxidative damage and chaperoning through direct stabilization of membranes and/or proteins [46; 47]. Many genes involved in the synthesis of these osmoprotectants have been explored for their potential in engineering plant abiotic stress tolerance [10,47].

The cellular and metabolic processes involved in salt stress are similar to those occurring in drought-affected plants and are responses to the osmotic effect of salt [48, 49]. As described above, the use of genes related to osmoprotectant synthesis has been successfully used in developing drought-tolerant crops and the transfer of glycine betaine intermediates have improved the drought and salt tolerance of transgenic plants in many cases [50].

The amino acid proline is known to occur widely in higher plants and normally accumulates in large quantities in response to environmental stresses [51,52]. The osmoprotectant role of proline has been verified in some crops by overexpressing genes involved in proline synthesis [53].

Other approaches successfully developed in a variety of crops to obtain abiotic-stresstolerant plants by transgenesis, have been manipulation of transcription factors (TFs), late embryogenesis abundant (LEA) proteins, and antioxidant proteins [54].On the other hand, the use of genetic and genomic analysis to identify DNA molecular markers associated to stress resistance can facilitate breeding strategies for crop improvement. This approach is particularly useful when targeting characters controlled by several genes, as in the case of most abiotic stress.

The potential to map different Quantitative Trait Loci (QTL) contributing to an agronomical trait and to identify linked molecular markers opens up the possibility to transfer 
simultaneously several QTLs and to pyramid QTLs for several agronomical traits in one improved cultivar [55]. However, the application of molecular markers in breeding programs requires preliminary studies to identify and validate potential markers [55].

Although the use of Marker-Assisted Selection may be helpful for crop improvement, its practical application in genetic improvement of resistance or tolerance to stress has been limited since no many stress tolerance QTL have been identified [56]. For future biotechnology improvements such as tolerance to drought or nutrient limitation, forward breeding will be necessary to co-optimize transgenic expression and genetic background because endogenous genes and environmental factors may have the potential to influence the phenotypes resulting from transgenic modifications [57].

It is important to point that genetic modification of higher plants by introducing DNA into their cells is a highly complex process. Practically any plant transformation experiment relies at some point on cell and tissue culture. Although the development transformation methods that avoid plant tissue culture have been described for Arabidopsis, and have been extended to a few crops, the ability to regenerate plants from isolated cells or tissues in vitro is needed for most plant transformation systems. Not all plant tissue is suited to every plant

\begin{tabular}{|l|c|c|}
\hline Plant species & stress & References \\
\hline Ipomoea batatas (sweet potato) & salt & {$[16]$} \\
\hline Triticum aestivum (wheat) & salt & {$[80]$} \\
\hline Oryza sativa (rice) & salt/drought & {$[81]$} \\
\hline Lactuca sativa (lettuce) & drought/cold & {$[82]$} \\
\hline Brassica juncea (mustard) & Cd & {$[83]$} \\
\hline Medicago sativa (alfalfa) & freezing & {$[84]$} \\
\hline Gossypium hirsutum (cotton) & chilling & {$[85]$} \\
\hline Solanum tuberosum (potato) & salt-drought & {$[86]$} \\
\hline Avena sativa (oat) & osmotic & {$[87]$} \\
\hline Daucus carota (carrot) & salt & {$[88]$} \\
\hline Zea mays (maize) & drought & {$[89]$} \\
\hline Pinus taeda (loblolly pine) & salt & {$[90]$} \\
\hline Populus tomentosa (chinese white poplar) & salt & {$[91]$} \\
\hline Citrus sinensis $x$ Poncirus trifoliate (Carrizo citrange) & drought & {$[92]$} \\
\hline Petunia sp. (petunia) & drought & {$[93]$} \\
\hline Nicotiana tabacum (tobacco) & freezing/Al & {$[94]$} \\
\hline Brassica juncea (indian mustard) & As and Cd & {$[95]$} \\
\hline Brassica napus (rape) & freezing & {$[96]$} \\
\hline Pinus virginiana (Virginia pine) & metal & {$[90]$} \\
\hline Hordeum vulgare (barley) & Al & {$[97]$} \\
\hline Alyssum sp. (alyssum) & Ni & {$[98]$} \\
\hline Table (Centic & \\
\hline
\end{tabular}

Table 2. Genetic transformation for increased resistance to abiotic stresses. 
transformation method, and not all plant species can be regenerated by every method [58]. There is, therefore, a need to find both a suitable plant tissue culture/regeneration regime and a compatible plant transformation methodology. Today, many agronomical and horticultural important species are routinely transformed, and the list of species that is susceptible to Agrobacterium-mediated transformation seems to grow daily (Table 2).

\section{In vitro tissue culture as a tool for physiological and biochemical studies in plants}

Because of the great interest for both basic and applied research, many scientific endeavours have long addressed the understanding of the mechanisms underlying the stress response and the identification of the specific genes/metabolites that are responsible for tolerance phenotypes.

In the last decades, in vitro culture of plants has become an integral part of advances in plant science research. Plant tissue culture techniques allow for close monitoring and precise manipulation of plant growth and development, indeed, the in vitro system offers the advantage that relatively little space is needed to culture plants and this system allows a rigorous control of physical environment and nutrient status parameters, which are difficult to regulate with traditional experimental system [59]. Furthermore, any complex organorgan and plant-environment interaction can be controlled or removed, and the level of stress can be accurately and conveniently controlled [60]. All this together makes that some aspects of plant growth, that were barely understood before the advancement of the science of tissue culture, such as the metabolism and interaction of plant hormones, as well as their physiological effects can be deeply studied [61].

Shoot apex culture has been widely used to evaluate plant physiological responses to salinity and osmotic stress in various species, including apple [59], olive [62] and tomato [63]. With regard to the whole plant, a similar response to salt stress could be expected in plantlets grown through in vitro shoot apex culture [63], because such explants can be considered mini-replicas of a plant with anatomical organization and ability to root and grow into whole plant.

We have previously described the use of an in vitro tissue culture technique to study the performance of different citrus genotypes cultured under salt stress conditions, avoiding the effect of the root by culturing shoots without the root system. The method proved to be a good tool for studying biochemical processes involved in the response of citrus to salt stress [64]. Some citrus genotypes have been classified as relatively salt tolerant under field conditions due to their ability to restrict chloride ions to roots while others have proved to be more sensitive to salinity [65].

In vitro tissue culture approach allowed us to observe that when shoots are cultured without a root system, all genotypes accumulated the same chloride levels and exhibited similar leaf damage as a consequence of salt stress treatment. There was no increase of malonyldialdehyde 
levels in any genotype, and common patterns of hormonal signaling were observed among genotypes. On the view of these results we concluded that under the same salt conditions and with the same level of leaf chloride intoxication, no biochemical differences exist among tolerant and sensitive genotypes. This points to the roots as a key organ not only as a filter of chloride ions but also as a signalling system in citrus [64]. In vitro tissue culture provided the tools to perform this studies that it would be impossible to carry out with whole plants grown under field or greenhouse conditions.

\section{Conclusion}

Use of in vitro cell and tissue-based systems offers a remarkable tool for dissecting the physiological, biochemical and molecular regulation of plant development and stress response phenomena. In recent years, considerable progress has been made regarding the development and isolation of stress tolerant genotypes by using in vitro techniques.

The most successful applied tools have been the induction of somaclonal variation and in vitro selection of plants tolerant to different abiotic stresses and the development of transgenic genotypes throughout different approaches.

In vitro selection makes possible to save the time required for developing disease resistant and abiotic stress tolerant lines of commercial crops and other plant species. However, in vitro selected variants should be finally field-tested to confirm the genetic stability of the selected traits under field conditions. The development of in vitro selection technology, together with molecular approaches and functional genomics will provide a new opportunity to improve stress tolerance in plants relevant to food production and environmental sustainability.

Development of transgenic plants using biotechnological tools has become important in plant-stress biology. Previous works on genetics and molecular approaches have shown that most of the abiotic stress tolerant traits are multigenic. Therefore, to improve stress tolerance several stress related genes need to be transfered. More recently manipulation of single transcription factors has provide the same effect as manipulation of multiple genes. This has become a promising approach to get abiotic stress tolerant crops.

A limiting factor for the widespread application of this technology is that, with few exceptions, genetic transformation protocols require plant regeneration of transformants using in vitro plant tissue culture tools. Although the list of species that are susceptible to Agrobacterium-mediated transformation has been increased recently, still are many genotypes for which regeneration protocols are not available.

On the other hand, plant tissue culture is also an invaluable laboratory tool to study basic aspects of plant growth and development, and to manipulate these processes since it makes possible to have a large number of plants in a small space, without the interference of other biotic or abiotic stress factors. It also allows growing plants in the same nutritional and environmental conditions all year around. 


\section{Author details}

Rosa Maㅗ Pérez-Clemente and Aurelio Gómez-Cadenas

Department of Agricultural Sciences. Universidad Jaume I. Campus Riu Sec. Castellón, Spain

\section{Acknowledgement}

This work was supported by the Spanish Ministerio de Economía y competitividad (MINECO) and Universitat Jaume I/Fundació Bancaixa through grants No. AGL2010-22195C03-01/AGR and P11B2009-01, respectively.

\section{References}

[1] Isendahl N., Schmidt G. Drought in the Mediterranean-WWF policy proposals; A. WWF Report, Madrid 2006.

[2] Jin T.C., Chang Q., Li W.F., Yin D.X., Li Z.J., Wang D.L., Liu B., Liu L.X. Stress-inducible expression of GmDREB1 conferred salt tolerance in transgenic alfalfa. Plant Cell Tissue and Organ Culture 2010; 100 219-227.

[3] Rengasamy P. Soil processes affecting crop production in salt-affected soils. Functional Plant Biology 2010; 37 255-263.

[4] Yang Y.L., Shi R.X., Wei X.L., Fan Q., An L.Z. Effect of salinity on antioxidant enzymes in calli of the halophyte Nitraria tangutorum Bobr. Plant Cell Tissue and Organ Culture 2010; 102 387-395.

[5] Gómez-Cadenas A., Arbona V., Jacas J., Primo-Millo E., Talon M. Abscisic acid reduces leaf abscission and increases salt tolerance in citrus plants. Journal of Plant Growth Regulation 2003; 21 234- 240.

[6] Wang W.X., Vinocur B., Shoseyov O., Altman A. Biotechnology of plant osmotic stress tolerance: physiological and molecular considerations. Acta Horticulturae 2001; 560 285-292.

[7] Jewell M.C., Campbell B.C, Godwin I.D. transgenic plants for abiotic stress resistance. In: Transgenic Crop Plants. C. Kole et al. (eds.), pringer-Verlag Berlin Heidelberg. 2010

[8] Wang W., Vinocur B., Altman A. Plant responses to drought, salinity and extreme temperatures: towards genetic engineering for stress tolerance. Planta 2003; 218 1-14.

[9] Cheong Y.H., Chang H.S., Gupta R., Wang X., Zhu T., Luan S. Transcriptional profiling reveals novel interactions between wounding, pathogen, abiotic stress, and hormonal responses in Arabidopsis. Plant Physiology 2002; 129: 661-677.

[10] Vinocur B., Altman A. Recent advances in engineering plant tolerance to abiotic stress: achievements and limitations. Current Opinion in Biotechnology 2005; 16 123-132.

[11] Rai M.K., Kalia R .K., Singh R., Gangola M.P., Dhawan A.K. Developing stress tolerant plants through in vitro selection-An overview of the recent progress. Environmental and Experimental Botany 2011; 71 89-98. 
[12] Sakhanokho H.F., Kelley R.Y. Influence of salicylic acid on in vitro propagation and salt tolerance in Hibiscus acetosella and Hibiscus moscheutos (cv 'Luna Red') African Journal of Biotechnology 2009; 8 1474-1481.

[13] Benderradji L., Brini F., Kellou K., Ykhelf N., Djekoun A., Masmoudi K., Bouzerour. H. Callus induction, proliferation, and plantlets regeneration of two bread wheat (Triticum aestivum L.) genotypes under saline and heat stress conditions. 2012 ISRN Agronomy, Article ID 367851.

[14] Lestari E.G. In vitro selection and somaclonal variation for biotic and abiotic stress tolerance. Biodiversitas 2006; 7 297-301.

[15] Kaeppler S.M., Kaepler H.F., Rhee Y. Epigenetic aspects of somaclonal variation in plants. Plant Molecular Biology. 2000; 43: 179-188.

[16] Gao X., Yang D., Cao D., Ao M., Sui X., Wang Q., Kimatu J., Wang L. In vitro micropropagation of Freesia hybrida and the assessment of genetic and epigenetic stability in regenerated plantlets. Journal of Plant Growth Regulation 2010; 29 257-267.

[17] Predieri S. Mutation induction and tissue culture in improving fruits. Plant Cell Tissue and Organ Culture 2001; 64 185-210.

[18] Jain S.M. Tissue culture-derived variation in crop improvement. Euphytica 2001; 118 153-166.

[19] Biswas M.K., Dutt M., Roy U.K., Islam R., Hossain M. Development and evaluation of in vitro somaclonal variation in strawberry for improved horticultural traits. Scientia Horticulturae 2009; 122 409-416.

[20] Matkowski A. Plantin vitro culture for the production of antioxidants - A review. Biotechnology Advances 2008; 26 584-560.

[21] Zair I., Chlyah A., Sabounji K., Tittahsen M., Chlyah H. Salt tolerance improvement in some wheat cultivars after application of in vitro selection pressure. Plant Cell Tissue and Organ Culture 2003; 73 237-244.

[22] Orbović V., Ćalović M., Viloria Z., Nielsen B., Gmitter F., Castle W., Grosser J. Analysis of genetic variability in various tissue culture-derived lemon plant populations using RAPD and flow cytometry. Euphytican 2008; 161 329-335.

[23] Rozema J., Flowers T. Crops for a salinized world. Science 2008; 322 1478-1480.

[24] Woodward A.J., Bennett I.J. The effect of salt stressand abscisic acidon proline production, chlorophyll content and growth of in vitro propagated shoots of Eucalyptus camaldulensis. Plant Cell Tissue and Organ Culture 2005; 82 189-200.

[25] Mohamed M.A.H., Harris, P.J.C., Henderson, J. In vitro selection and charac-terisation of a drought tolerant clone of Tagetes minuta. Plant Science 2000; 159 213-222.

[26] Hassan N.M., Serag M.S., El-Feky F.M. Changes in nitrogen content and protein profiles following in vitro selection of $\mathrm{NaCl}$ resistant mung bean and tomato. Acta Physiologiae Plantarum 2004; 26 165-175.

[27] Verslues P.E., Ober E.S., Sharp R.E. Root growth and oxygen relations at low water potentials. Impact of oxygen availability in polyethylene glycol solutions. Plant Physiology 1998; 116 1403-1412. 
[28] Lascano H.R. Antioxidant system response of different wheat cultivars under drought: field and in vitro studies. Australian Journal of Plant Physiology 2001; 281095 - 1102.

[29] Hossain Z., Mandal A.K.A., Datta S.K., Biswas A.K. Development of $\mathrm{NaCl}$ tolerant line in Chrysanthemum morifolium Ramat. through shoot organogenesis of selected callus line. Journal of Biotechnology. 2007; 129 658-667.

[30] Parida A.K., Das A.B. Salt tolerance and salinity effects on plants: a review. Ecotoxicology and Environmental Safety 2005; 60 324-349.

[31] Demiral T., Turkan, I. Comparative lipid peroxidation, antioxidant defense systems and proline content in roots of two rice cultivars differing in salt tolerance. Environmental and Experimental Botany. 2005; 53 247-257.

[32] Queiros F., Fidalgo F., Santos I., Salema R. In vitro selection of salt tolerant cell lines in Solanum tuberosum L. Biologia Plantarum. 2007; 51 728-734.

[33] Ghoulam C., Ahmed F., Khalid F. Effects of salt stress on growth, inorganic ions and proline accumulation in relation to osmotic adjustment in five sugar beet cultivars. Environmental and Experimental Botany 2001; 47 139-150.

[34] Aazami M.A., Torabi M., Shekari F. Response of some tomato cultivars to sodium chloride stress under in vitro culture condition African Journal of Agricultural Research. 2010; $52589-2592$.

[35] Todaka D., Nakashima K., Shinozaki K., Yamaguchi-Shinozaki K. Toward understanding transcriptional regulatory networks in abiotic stress responses and tolerance in rice. Todaka et al. Rice 2012, 5:6 http://www.thericejournal.com/content/5/1/6.

[36] Kosová, K., Vítámvás, P., Prášil, I.T. Renaut, J. Plant proteome changes under abiotic stress - Contribution of proteomics studies to understanding plant stress response. Journal of Proteomics, 2011; 15 51-58.

[37] Cevallos-Cevallos, J. M., Reyes De Corcuera, J. I., Etxeberria, E., Danyluk, M. D. Rodrick, J. E. Metabolomic analysis in food science: a review. Trends in Food Science and Technology 2009; 20 557-566.

[38] Palama T., Menard P., Fock I., Bourdon E., Govinden-Soulange J., Bahut M., Payet B., Verpoorte R., Kodja H. Shoot differentiation from protocorm callus cultures of Vanilla planifolia (Orchidaceae): proteomic and metabolic responses at early stage. BMCP Plant Biology 2010; 1082.

[39] Miflin B. Crop improvement in the $21^{\text {st }}$ century. Journal of Experimental Botany 2000; 51 1-8.

[40] Gómez-Cadenas A, Tadeo Fr, Primo-Millo E, Talón M. Involvement of abscisic acid and ethylene in the response of citrus seedlings to salt shock. Physiologia Plantarum 1998; 103 475- 484.

[41] Arbona V, Gómez-Cadenas A. Hormonal modulation of citrus responses to flooding. Journal of Plant Growth Regulation 2008; 27 241-250.

[42] Schwartz S.H., Qin X., Zeevaart J.A.D. Elucidation of the indirect pathway of abscisic acid biosynthesis by mutants, genes, and enzymes. Plant Physiology 2003; 131 15911601. 
[43] Park H.Y., Seok H.Y., Park B.K., Kim S.H., Goh C.H., Bh L., Lee C.H., Moon Y.H. Overexpression of Arabidopsis ZEP enhances tolerance to osmotic stress. Biochemical and Biophysical Research Communications 2008; 375: 80-85.

[44] Al-Abed D., Madasamy P., Talla R., Goldman S., Rudrabhatla S. Genetic engineering of maize with the Arabidopsis DREB1A/CBF3 gene using split-seed explants. Crop Science 2007; 47 2390-2402.

[45] Trujillo L.E., Sotolongo M., Menendez C., Ochogavia M.E., Coll Y., Hernandez I., Borras-Hidalgo O.,Thomma B.P.H.J., Vera P., Hernandez L. SodERF3, a novel sugarcane ethylene responsive factor (ERF), enhances salt and drought tolerance when overexpressed in tobacco plants. Plant and Cell Physiology 2008; 49 512-525.

[46] McNeil S.D., Nuccio M.L., Hanson A.D. Betaines and related osmoprotectants. Targets for metabolic engineering of stress resistance. Plant Physiology 1999; 120 945-949.

[47] Zhang Y.Y., Li Y., Gao T., Zhu H., Wang D.J., Zhang H.W., Ning Y.S., Liu L.J., Wu Y.R., Chu C.C., Guo H.S., Xie Q. 2008 Arabidopsis SDIR1 enhances drought tolerance in crop plants. Biosci Biotechnol Biochem 72: 2251-2254.

[48] Yeo A.R., Lee K.S., Izard P., Boursier P.J., Flowers T.J. Short- and long-term effects of salinity on leaf growth in rice (Oryza sativa L.). Journal of Experimental Botany 1991; 42 881-889.

[49] Munns R., Tester M. Mechanisms of salinity tolerance. Annual Review of Plant Physiology 2008; 59 651-681.

[50] Wu W., Su Q., Xia X., Wang Y., Luan Y., An L. The Suaeda liaotungensis kitag betaine aldehyde dehydrogenase gene improves salt tolerance of transgenic maize mediated with minimum linear length of DNA fragment. Euphytica 2008; 159 17-25.

[51] Kavi Kishore P.B., Sangam S., Amrutha R.N., Laxmi P.S., Naidu K.R., Rao K.R.S.S., Rao S., Reddy K.J., Theriappan P., Sreenivasulu N. Regulation of proline biosynthesis, degradation, uptake and transport in higher plants: its implications in plant growth and abiotic stress tolerance. Current Science 2005; 88 424-438.

[52] Ashraf M., Foolad M.R. Roles of glycine betaine and proline in improving plant abiotic stress resistance. Environmental and Experimental Botany 2007; 59 206-216.

[53] Hmida-Sayari A., Gargouri-Bouzid R., Bidani A., Jaoua L., Savoure A., Jaoua S. Overexpression of $\mathrm{D}^{1}$-pyrroline-5-carboxylate synthetase increases proline production and confers salt tolerance in transgenic potato plants. Plant Science 2005; 169 746-752.

[54] Umezawa T., Fujita M., Fujita Y., Yamaguchi-Shinozaki K., Shinozaki K., Engineering drought tolerance in plants: discovering and tailoring genes to unlock the future. Current Opinion in Biotechnology 2006; 17 113-122.

[55] Yu K.F., Park S.J., Zhang B.L., Haffner M. Poysa V. An SSR marker in the nitrate reductase gene of common bean is tightly linked to a major gene conferring resistance to common bacterial blight. Euphytica 2004; 138: 89-95.

[56] Foolad, M.R., Recent advances in genetics of salt tolerance tomato. Plant Cell Tissue and Organ Culture 2004; 76: 101-119. 
[57] Mumm R.H. Backcross versus forward breeding in the development of transgenic maize hybrids: theory and practice. Crop Science (Suppl 3) 2007; 47: 164-171.

[58] Benson E.E. Special symposium: in vitro plant recalcitrance In vitro plant recalcitrance: an introduction. In Vitro Cellular and Developmental Biology Plant 2000; 36:141-148.

[59] Shibli R.A., Smith M.A.L., Spomer L.A. Osmotic adjustment and growth responses of three Chrysanthemum morifolium Ramat cultivars to osmotic stress induced in vitro. Journal of Plant Nutrition, 1992; 15 1374-1381.

[60] Stephen R.G., Zeng L., Shannon M.C., Roberts S.R. Rice is more sensitive to salinity than previously thought. Annual Report of U.S. Department of Agriculture's Research Service, pp: 481. 2002.

[61] Bairu M.W., Kane M.E. Physiological and developmental problems encountered by in vitro cultured plants. Plant Growth Regulation 2011; 63 101-103

[62] Shibli R.A., Al-Juboory K. Comparative response of 'Nabali' olive microshoot, callus and suspension cell cultures to salinity and water deficit. Journal of Plant Nutrition 2002; 25 61-74.

[63] Cano E.A., Perez-Alfocea F., Moreno V., Caro M., Bolarin, M.C. Evaluation of salt tolerance in cultivated and wild tomato species through in vitro shoot apex culture. Plant Cell, Tissue and Organ Culture 1998; 53 19-26.

[64] Montoliu A., López-Climent M.F., Arbona V., Pérez-Clemente R.M., Gómez-Cadenas A. A novel in vitro tissue culture approach to study salt stress responses in citrus. Plant Growth Regulation 2009; 59 179-187.

[65] López-Climent M.F., Arbona V., Pérez-Clemente R.M., Gómez-Cadenas A. Relationship between salt tolerance and photosynthetic machinery performance in citrus. Environmental and Experimental Botany 2008; 62 176-184.

[66] Hossain Z., Mandal A.K.A., Datta S.K., Biswas A.K., Development of $\mathrm{NaCl}$ tolerant line in Chrysanthemum morifolium Ramat. through shoot organogenesis of selected callus line. Journal of Biotechnology. 2007; 129 658-667.

[67] Rahman, M.H., Krishnaraj, S., Thorpe, T.A. Selection for salt tolerance in vitro using microspore-derived embryos of Brassica napus cv. Topas, and the characterization of putative tolerant plants. In Vitro Cellular and Developmental Biology - Plant 1995; 31 116-121.

[68] Koc N.K., Bas B., Koc M., Kusek M. Investigations of in vitro selection for salt tolerant lines in sour orange (Citrus aurantium L.). Biotechnology 2009; 8 155-159.

[69] Kripkyy O., Kerkeb L., Molina A., Belver A., Rodrigues Rosales P., Donaire P.J., Effects of salt-adaptation and salt-stress on extracellular acidification and microsome phosphohydrolase activities in tomato cell suspensions. Plant Cell Tissue and Organ Culture. 2001; 66 41-47.

[70] He S., Han Y., Wang Y., Zhai H., Liu Q. In vitro selection and identification of sweetpotato (Ipomoea batatas (L.) Lam.) plants tolerant to $\mathrm{NaCl}$. Plant Cell Tissue and Organ Culture 2009; 96: 69-74. 
[71] Gandonou C.B., Errabii T., Abrini J., Idaomar M., Senhaji N.S. Selection of callus cultures of sugarcane (Saccharum sp.) tolerant to $\mathrm{NaCl}$ and their response to salt stress. Plant Cell Tissue and Organ Culture. 2006; 87 9-16.

[72] Ochatt S.J., Marconi P.L., Radice S., Arnozis P.A., Caso O.H. In vitro recurrent selection of potato: production and characterization of salt tolerant cell lines and plants. Plant Cell Tissue and Organ Culture 1999; 55 1-8.

[73] Barakat, M.N., Abdel-Latif, T.H. In vitro selection of wheat callus tolerant to high levels of salt and plant regeneration. Euphytica 1996; 91 127-140.

[74] Purushotham M.G., Patil V., Raddey P.C., Prasad T.G., Vajranabhaiah S.N. Development of in vitro PEG stress tolerant cell lines in two groundnut (Arachis hypogaea L.) genotypes. Indian Journal of Plant Physiology. 1998; 3 49-51.

[75] Gangopadhyay G., Basu S., Gupta S. In vitro selection and physiological characterization of $\mathrm{NaCl}$ - and mannitol-adapted callus lines in Brassica juncea. Plant Cell Tissue and Organ Culture. 1997; 50 161-169.

[76] Errabii T., Gandonou C.B., Essalmani H., Abrini J., Idomar M., Senhaji N.S. Growth, proline and ion accumulation in sugarcane callus cultures under drought-induced osmotic stress and its subsequent relief. African Journal of Biotechnology. 2006; 5 14881493.

[77] Roy B., Mandal A.B. Towards development of Al-toxicity tolerant lines in indica rice by exploiting somaclonal variation. Euphytica 2005; 145 221-227.

[78] Mariska I. Peningkatan Ketahanan terhadap Alumunium pada Pertanaan Kedelai melalui Kultur in Vitro. Laporan RUT VIII. Bidang Teknologi Pertanian. Bogor: Balai Penelitian Bioteknologi Pertanian \& Kementerian Riset dan Teknologi RI-LIPI. 2003

[79] Samantaray S., Rout G.R., Das P. In vitro selection and regeneration of zinc tolerant calli from Setaria italica L Plant Science. 1999; 31 201-209.

[80] Laurie S., Feeney K.A., Mathuis F.J., Heard P.J., Brown S.J., Leigh R.A. A role for HKT1 in sodium uptake by wheat roots, Plant Journal 2002; 32 139-49.

[81] Liu K., Lei W., Xu Y., Chen N., Ma Q., Li F., Chong K. Overexpression of OsCOIN, a putative cold inducible zinc finger protein, increased tolerance to chilling,salt and drought, and enhanced praline level in rice. Planta, 2007; 226 1007-1016.

[82] Vanjildorj E., Bae T.W., Riu K.Z., Kim S.Y., Lee H.Y. Overexpression of Arabidopsis ABF3 gene enhances tolerance to drought and cold transgenic lettuce (Lactuca sativa). Plant Cell, Tissue and Organ Culture. 2005; 83 41-50.

[83] Zhu Y.L., Pilon-Smits E.A.H., Jouanin L., Terry N. Overexpression of Glutathione synthetase in indian mustard enhances cadmium accumulation and tolerance, Plant Physiology. 1999; 119: 73-80.

[84] Mckersie B.D., Chen Y., Beus M.D., Bowley S.R., Bowler C., Inze D.,. Halluin K.D, Botterman J. Superoxide dismutase enhances tolerance of freezing stress in transgenic alfalfa (Medicago sativa L.). Plant Physiology. 1993; 103: 1155-1163.

[85] Payton P., Webb R., Kornyeyev D., Allen R., Holaday A.S. Protecting cotton photosynthesis during moderate chilling at high light intensity by increasing 
chloroplastic antioxidant enzyme activity, Journal of Experimental Botany2001; 52 2345-2354.

[86] Babu V., Bansal K.C. Osmotin overexpression in transgenic potato plants provide protection against osmotic stress, 5th International Symposium on Molecular Biology of Potato, Bogensee, Germany, Aug 2-6. 1998

[87] Maqbool S.B., Zhong H., El-Maghraby Y., Ahmad A., Chai B., Wang W., Sticklen M.B. Competence of oat (Avena sativa L.) shoot apical meristems for integrative transformation, inherited expression and osmotic tolerance of transgenic lines containing HVA1, Theoretical and Applied Genetics. 2002; 105 201-208.

[88] Kumar S., Dhingra A., Daniell H. Plastid-expressed betaine aldehyde dehydrogenase gene in carrot cultured cells, roots, and leaves confers enhanced salt tolerance. Plant Physiology. 2004; 135 2843-2854.

[89] Ruidang Q., Mei S., Hui Z., Yanxiu Z., Juren Z. Engineering of enhanced glycine betaine synthesis improves drought tolerance in maize. Plant Biotechnology Journal., 2004; 2 477-486.

[90] Tang W., Peng X., Newton R.J. Enhanced tolerance to salt stress in transgenic loblolly pine simultaneously expressing two genes encoding mannitol-1-phosphate dehydrogenase and glucitol-6-phosphate dehydrogenase. Plant Physiology and Biochemistry., 2005: 43 139-146.

[91] Du N., Liu X., Li Y., Chen S., Zhang J., Ha D., Deng W., Sun C., Zhang Y., Pijut P.M. Genetic transformation of Populus tomentosa to improve salt tolerance. Plant Cell Tissue and Organ Culture 2012; 108 181-189.

[92] Molinari H.B.C., Marur C.J., Filho G.C.B., Kobayashi A.K., Pileggi M., Rui P.L. Jnr, Luiz F.P.P., Luiz G.E.V. Osmotic adjustment in transgenic citrus rootstock Carrizo citrange (Citrus sinensis Osb. x Poncirus trifoliata L. Raf.) overproducing proline. Plant Science, 2004; 167 1375-1381.

[93] Yamada M., Morishita H., Urano K., Shiozaki N., Yamaguchi-Shinozaki K., Shinozaki K., Yoshiba Y. Effects of free proline accumulation in petunias under drought stress. Journal of Experimental Botany, 2005; 56 1975-1981.

[94] Honjoh K., Shimizu H., Nagaishi N., Matsumoto H., Suga K., Miyamoto T., Iio M., Hatano S. Improvement of freezing tolerance in transgenic tobacco leaves by expressing the hiC6 gene. Bioscience, Biotechnology, and Biochemistry. 2001; 65 1796-1804.

[95] Gasic K., Korban S.S. Expression of Arabidopsis phytochelatin synthase in indian mustard (Brassica juncea) plants enhances tolerance for Cd and Zn. Planta, 200; 225 12771285.

[96] Savitch L.V., Allard G., Seki M., Robert L.S., Tinker N.A, Huner NPA, Shinozaki K, Singh J The effect of overexpression of two brassica CBF/DREB1-like transcription factors on photosynthetic capacity and freezing tolerance in Brassica napus. Plant Cell Physiology. 2005; 46 1525-1539.

[97] Furukawa J., Yamaji N., Wang H., Mitani N., Murata Y., Sato K., Katsuhara M., Ma K.T.J. An aluminum-activated citrate transporter in barley. Plant Cell Physiology. 2007; 48 1081-1091. 
[98] Ingle R.A., Mugford S.T., Rees J.D., Campbell M.M., Smith J.A.C. Constitutively high expression of the histidine biosynthetic pathway contributes to nickel tolerance in hyperaccumulator plants. Plant Cell, 2005: 17 2089-2106. 